Ewelina Świdrak*, PhD, https:/ / orcid.org/0000-0002-6815-5370

Anna Badora**, Phd, https://orcid.org/0000-0003-4027-6792

*Department of Family Pedagogy, Faculty of Social Sciences

The John Paul II Catholic University of Lublin

*Department of Didactics, School Education and Pedeutology,

Faculty of Social Sciences

The John Paul II Catholic University of Lublin

\title{
Expected and implemented skills, knowledge and attitudes of mentors in the light of Stefan Kunowski's theory of integral development in the opinion of education students
}

\author{
Oczekiwane i realizowane umiejętności, wiedza oraz postawy \\ mentorów, w świetle teorii integralnego rozwoju Stefana \\ Kunowskiego, w opinii studentów pedagogiki
}

https:// doi.org/10.34766/ fetr.v48i4.780

\begin{abstract}
The main purpose of the presented article is to determine the expected and implemented skills, knowledge and attitudes of mentors, in the opinion of education students and in the light of Stefan Kunowski's theory of integral development.

The first part provides a brief overview of the ways mentoring itself is understood. The second part is a theoretical analysis of the mentor's influence in the perspective of the theory of integral development of the Polish educator Stefan Kunowski. The third part presents data obtained as a result of the conducted empirical research. The article ends with main research conclusions.
\end{abstract}

Keywords: mentoring, integral development, life-long education

\begin{abstract}
Abstrakt: Głównym celem przedstawionego artykułu jest określenie jakie, w ocenie studentów pedagogiki są oczekiwane i realizowane umiejętności, wiedza i postawy mentorów, w świetle teorii integralnego rozwoju Stefana Kunowskiego.

W pierwszej części zawarto krótki przegląd sposobów rozumienia samego mentoringu. Część druga stanowi analizę teoretyczną sposób oddziaływania mentora $\mathrm{w}$ perspektywie teorii integralnego rozwoju polskiego pedagoga Stefana Kunowskiego. W części trzeciej przedstawiono dane uzyskane w wyniku przeprowadzonych badań empirycznych. Jako zwieńczenie artykułu sformułowano główne wnioski badawcze.
\end{abstract}

Słowa kluczowe: mentoring, rozwój integralny, kształcenie ustawiczne

\section{Introduction}

The use of the term mentoring has not been popularised in Poland so far, despite the fact that activities in this field are dynamically undertaken in this country. The procedure of professional advancement which teachers have to follow assumes that at each stage of 
professional improvement, the teacher is accompanied by another senior teacher. The scope of duties of the internship coordinator is regulated by a legal document called the Teacher's Charter, Art. 9c. In addition, teachers receive support from various types of institutions, such as the Teacher Training Centre, psychological and pedagogical counselling centres or universities.

\section{The concept of mentoring}

In the traditional sense, mentoring at work was understood as transferring knowledge and professional experience by older colleagues to people who begin their careers (Roberts 2000). It was called dyadic (dyadic one-to-one mentoring) and concerned two persons: the mentor and the mentee, who by definition did not always create an equal relationship. With regard to teaching, it is emphasised that mentoring plays an important role for teachers who begin their work and for those who want to improve their qualifications and strengthen their professional position (Fresko,Wertheim, 2006; Dorner, Kárpáti 2010; Achinstein, Fogo, 2015). In education, mentoring pairs the novice with an expert, veteran teacher focused on supporting the novice's professional development in his or her first few years of full time teaching (Achinstein, Fogo, 2015).

Currently, in the field of education, the definition of mentoring as well as the range of characteristics of people who can be involved in the mentor-mentee relationship are broadening. For example, concepts are developed in which the mentor may be a group of professionals who learn from each other, equal in the professional hierarchy (Pennanen, Heikkinen, Tynjälä, 2020). For example in the situation of online learning more often the young teachers' role in mentoring is analysed (Martin, Michaud, Logerstedt, 2019). Young people train older people in digitization and social networks, while older people share their leadership and life experiences. It is called reverse mentoring (Jauslin, Hernández \& Schulte, 2021). Brownie (2021) emphasises that on line mentoring might be more effective that traditional one. One-to-one online meetings often seem relaxed and open. Mentees appear more willing to express their feelings and thoughts as they rest comfortably in familiar room (Browne, 2021). Another topic discussed in this area is youth mentoring among students in bloom-in schools, youth sports leagues, and community organizations (Rhodes, 2020).

It is also worth broadening the possible scope of the mentor-mentee relationship to include students who are not yet teachers, but who are preparing for the teaching profession. In Poland, the first situation in which future teachers experience mentoring is the internship during their university education, held each year of study. In accordance with the study syllabus, internships for students last 180 hours for the entire three-year cycle of BA studies. They are an integral part of the syllabus for the course of study in Education ${ }^{1}$. Completing

${ }^{1}$ http:/ /isap.sejm.gov.pl/isap.nsf/DocDetails.xsp?id=WDU20190001450 
the internship is one of the necessary conditions for graduating and obtaining qualifications for working as a teacher or counsellor. The internships are unpaid. The number of hours given here indicates the time spent in a given educational setting where the student holds his or her internship, and planned according to the schedule and programme drawn up in consultation with the mentor.

As part of compulsory internships, each student is assigned a teacher working in a given educational institution, officially known as a mentor, who helps future teachers to assume the new professional role. In this context, it is important to determine what skills, knowledge and attitudes, according to students, are implemented by the mentors in the relationship with the mentee. In view of the above changes in the understanding of mentoring, it is also emphasised that the position of the mentor and mentee in the mentoring process should be equal and enable the development of both sides of the process. It is emphasised in the literature that the competencies of mentors in relation to their mentees are subject to evolution. Mentors learn from their mentees and change their strategies depending on the situation (Kowalski 2019). Therefore, modern mentoring in education cannot be limited to the relationship of older teachers taking care of younger teachers, but should be part of the trend of life-long education, in which support is multifaceted and occurs at different stages of life.

\section{Mentor's knowledge, skills and attitudes in the light of Stefan Kunowski's} theory of integral development

In her research, Baran (2017) distinguished 15 key competencies that a mentor should have in any organisation. These are: quality of information transfer, providing help to others, providing information, transferring knowledge, delegating tasks, sharing experience, cooperation, encouraging others to be independent, regularly holding conversations, respecting the knowledge and skills of others, the ability to draw conclusions for the future, establishing one's authority in a team, the ability to listen to others in a team and take into account their opinions, supporting other employees in their development. Other studies have pointed out that, apart from reliable knowledge transfer by mentors, personal and social support is also important in mentoring (Geeraerts et al. 2015). Emotional, social and personal aspects in the relationship between the mentor and the mentee, which significantly contribute to the acquisition of knowledge necessary in professional work, have gained in importance, for example self-awareness, life scripts, personal and moral qualities, emotional climate; non-judgemental communication; psychological projection; empathy; developing a pro-social culture; (Thompson, 2019).

The research presented above indicates individual competencies that a mentor should demonstrate. In the present article, however, we assume that effective mentoring, and 
especially that carried out in education, cannot be formed around individual competencies, but rather around a certain system of competencies. We assume that activities in the field of mentoring constitute a continuation of education, and thus should fulfil the main goal of educational and didactic processes, that is, the comprehensive development of the learner. In this context, we assume that the knowledge, skills and attitudes represented by the mentor should relate to different aspects of the person. Therefore, in order to develop a system of knowledge, skills and attitudes that should characterise a mentor, the concept of integral education by the Polish educator Stefan Kunowski was used (Rynio, 2016).

The main link in the lifelong learning process is, among others, the mentor's profile and the knowledge, skills and attitudes that should be displayed in the relationship with the mentee. We assume that this relationship is a continuation of the educational and didactic process; it is the next level of education for both the mentor and the mentee. S. Kunowski (2007) emphasises that educational assistance relates to a human being; it is not limited by the age of the learner. In this sense, we can assume that the mentor is the educator, and the young teacher is the learner. In accordance with this assumption, the main goal of the mentor is to strive for the integral development of the mentee.

The integrity of development relates to a person as a whole, respecting all aspects of their functioning, W. Flitner writes about the peculiar multi-layered nature of man (after: Herrmann, 2015). According to this author, in all activities towards a person, he or she should be considered in four aspects as:

1. "A natural being.

2. In their historicity

3. As a spiritual being

4. In their activities."

The above perspectives of getting to know a person can also be a reference point for educational activities.

S. Kunowski lists the following layers of education:

"a) the biological layer - that constitutes our body,

b) the psychological layer - that develops the psyche as a whole,

c) the sociological layer - that forms the social person of the charge,

d) the culture-creating layer that develops a person into a creator of culture,

e) the purely spiritual or worldview layer - that fully shapes spirituality and its religious and moral side" (after: Chałas, 2020, pp. 135-136).

The author points out that also in the educational and didactic process, the participating subjects constitute multi-layered individualities. The balanced development of each layer is essential to the achievement of full humanity.

In this context, it becomes important to determine what range of impacts the mentor can exert in particular layers by establishing a relationship with the mentee. 


\subsection{The biological layer}

It relates to physicality and carnality. It is the entire genetic "endowment" of a person. In the mentoring process, one of the basic tasks of the mentor is showing concern for the mentee's health and safety. B. Davis and K. Higdon (2008), when examining the effectiveness of a support programme for beginning teachers, distinguished the most important aspect of these activities - the actual support resulting from the availability of the mentor. This means that by actually participating in the mentoring process, the mentor gives the mentee a feeling of stability. Activities involving subsequent layers can only be carried out once the groundwork has been laid in this way.

\section{2. The psychological layer}

According to S. Kunowski (2007), its scope covers emotions, knowledge and cognitive skills. One of the main tasks of the mentor is to introduce the young teacher to the secrets of the profession. Hence, an indispensable element in mentoring is sharing the resources of experience and knowledge with the mentee. As D. Richter et al. (2013, p. 168) points out, "conventional mentoring focuses on situational adjustment to the new school environment, technical advice, and emotional support. Moreover, conventional approaches view the beginning teacher as a recipient of knowledge and the mentor as the expert teacher."

In this study, it is assumed that the mentor's authority does not close him or her to the knowledge and creativity of the young teacher. As I. Wagner, H. Wiśniewska-Śliwińska (2019) points out, the teacher does not give in to routine and treats the students' young age as an inexhaustible potential of originality and inspiration.

The assumption is that the mentor should present his or her professional achievements to the mentee, at the same time leaving space for their actions and mistakes. In addition, accompanying young teachers at the beginning of the career path, the mentor also draws inspiration, modifies and improves his or her own professional skills. He or she is aware of the need to constantly develop himself or herself; therefore, he or she is open to the new.

It should be emphasised that one's impressive amount of practical knowledge does not ultimately determine the proper course of the mentoring process. The emotional support and acceptance of the mentee is also significant. R. Ballantyne, B. Hansford and J. Parker (1995, p. 304) conducted a study among young teachers in which they demonstrated that in the first week of work the teacher needs general emotional support from the mentor, and after a few weeks, the scope of this help changes to looking for solutions to specific problems, e.g. managing students with learning difficulties or with problems with behaviour. Thus, emotional support precedes the process of sharing the possessed knowledge, helps build trust and establish a relationship between two autonomous mutually 
accepting subjects. Walikington (2005) emphasises that not every teacher is ready for personal emotional involvement that the role of a mentor requires, but mentoring cannot be a mere transfer of knowledge and experience.

\subsection{The social layer}

In S. Kunowski' s theory (2007), it contains all the relationships that a person establishes, as well as the roles and functions that he or she assumes and performs in them, creating a wider network of social contacts.

With regard to S. Kunowski's theory of development, we assume that the relationship that the mentee establishes with the mentor becomes a prototype that, with modifications, will be reproduced in subsequent contacts. A. Roehrig, C. Bohn, J. Turner and M. Pressley (2008) emphasise in their analyses that the quality of communication between the mentor and the mentee is a factor that determines the effectiveness of mentoring for beginning teachers. The appropriate level of openness to the other subject and total, two-way commitment to the relationship determine the occurrence of effective communication, which, in turn, fulfils two functions, indicated also by J. Boreen (2009):

1) enables the improvement of one's professional skills through a joint analysis of the encountered problems;

2) creates a model of a correct relationship that should exist between the educator and the charge.

In turn, S. Bressman, J.S.Winter, S. E. Efron (2018) note that a specific bond is built between the mentor and the mentee, which does not relate solely to the professional sphere. A high level of trust, openness and commitment shapes a special relationship of companionship and even friendship, while maintaining the educator-learner structure, according to the criterion of richer professional and life experience.

The effect of the mentor on the social layer of the mentee takes place not only in their two-subject relationship. R. Viney and J. McKimm (2010) also point to "a varied career and life experience, a wide professional network and commitment to their own professional development." The mentee learns the ways of social and professional functioning by observing the mentor, which is not limited to formal participation in the classes conducted by the him or her, but covers the entirety of the mentor's activities carried out both among students, the teaching staff and towards themselves. The behaviours that the mentor presents in certain situations and the attitudes they adopt towards other people are a reference point in modelling the social layer of a young teacher. 


\subsection{The culture-creating layer}

According to S. Kunowski, the culture-creating layer contains a person's predispositions to consciously receive culture, as well as to responsibly and innovatively cocreate it. We assume that in the implementation of effective mentoring, the culture of the school is both a context for its occurrence and a factor that dynamises the entire process. $\mathrm{L}$. Orland-Barak (2014) stresses that in designing mentoring activities, the following should be taken into account: mentors' supervisory behaviour should also consider their contextual understanding of the workplace, population and school culture within which they operate. It should be added that the mentor, through contextual participation in the culture of their school, knows its formal and informal rules. With such a resource of knowledge, they become a link between the new reality - that is, the mentee, and the known reality, i.e. the school culture.

The very quality of the school culture in which mentoring activities are implemented is also important for their success. M. Carter and R. Francis (2001, p. 256) indicate that the best mentoring relationships arise from a positive organisational climate in schools. In this context, the mentor-mentee relationship is not a closed space; on the contrary, it is characterised by openness, so that the school's culture, with all its subjects, can "participate" in this relationship. It should be emphasised, however, that this is not supervisory participation - characterised by exercising control, but rather supportive participation - a situation in which the mentee is surrounded with care, and characterised by understanding and kindness.

Knowledge of school conditions in which the mentor and the mentee function is an important aspect of the role of the mentor. S. Whitaker (2000) indicates that it is particularly important in special education. The researcher emphasises the legitimacy of introducing comentoring - precisely due to the differentiation of two spaces: the culture of special education and the local culture of the school in which the mentor and the mentee operate. These areas, although they interact with each other, are characterised by a different internal specificity with which teachers actively participating in it are familiarised.

When planning activities in relation to the mentee, the mentor should also include other subjects that represent the culture of a given school. It provides a chance to shape a conscious, multi-directional and active recipient and creator of the local culture of the school.

\subsection{The worldview layer}

According to S. Kunowski, the worldview layer includes the values realised by a person, his or her axiological systems, as well as religiosity and a sense of meaning and purpose in the endeavours one makes. It is a space for the transcendence of the person. E. Domagała- Zyśk (2018) points out “While the development of first four layers (biological, 
social, cultural and ideological) seems to be well understood and described in educational literature, it is still sometimes questioned whether or not the spiritual sphere (the fifth one) should belong to the students' integral development. Kunowski defined the spiritual dimension not in terms of the categories of a certain religious system, but as the young person's ability to turn to the highest ideal of Truth, Good and Beauty. Hence, thanks to the freedom to choose a good way he/she can take responsibility for his/her own behaviour and also be responsible for other persons" (ibidem, p. 185).

Relating the mentoring process to the concept of S. Kunowski, the mentor who introduces the mentee into the teaching profession does not separate this role from other aspects of his or her person. Hence, it is possible for the process of interception of values to occur, defined by K. Chałas (2016) as the process of accepting foreign goals, in which values exist, as one's own; channelling to one's interior and accepting as one's own the values created by the environment; it is expressed in man's conduct according to values. Both in relation to the mentee and in the overall behaviour of the mentor, he or she presents a specific system of values. Authenticity in its implementation introduces the young teacher to the presented axiological structures. However, this is not intrusive - on the contrary, the values that the mentor truly implements are only a model that the mentee can use voluntarily to form their own hierarchy of values.

In addition to the values with which the mentee comes into contact in the relationship with the mentor, they also see the specificity of meaning and purpose in educational activities. V. Frankl (1966a, p. 258) emphasises that "man is basically striving to find and fulfil meaning and purpose in life." The organisation of the educational and didactic process cannot be deprived of the conviction about the sense and importance of these activities. The mentor, introducing a young teacher to the professional path, shows them by his or her example and determination that the effort of educational activities is necessary, even when its effects seem to be difficult to observe.

As V. Frankl (1966b) points out, "In fact, it is a constitutive characteristic of being human that it always points, and is directed, to something other than itself. It is, therefore, a severe and grave misinterpretation of man to deal with him as if he were a closed system. Actually, being human profoundly means to be open to the world" (ibidem, p. 97). In this context, a mentor who wants to have a real impact on the spiritual layer of the mentee must place them in the centre of his or her actions, so that they can experience truthfully, and thus understand, that the meaning of education is the learner and their comprehensive development.

Each of the above-mentioned layers is important in human development. Nevertheless, at the same time, they are characterised by a certain hierarchy, resulting from their specificity and complexity. Additionally, they are not completely autonomous in their scopes, but interpenetrate and complement each other. 


\section{Authors' research}

\subsection{The aim of the research}

The aim of the research was to define and describe the knowledge, skills and attitudes of mentors - in the light of Stefan Kunowski's theory of integral development which, in the students' opinion, are of significance in preparing education students to follow the profession of a teacher.

The main problem of the article is expressed in the question:

In the opinion of education students, what skills, knowledge and attitudes of mentors from particular developmental layers distinguished by Stefan Kunowski can be identified that are important for following the teaching profession?

Specific research problems:

P1: What knowledge, skills and attitudes from particular developmental layers do education students expect from their mentors during their internships?

P2: What knowledge, skills and attitudes from particular developmental layers distinguished by Stefan Kunowski characterised the teachers-mentors during internships in educational institutions in the opinion of students?

P3:What gaps in knowledge, skills and attitudes from particular developmental layers were noticed by students among their internship mentors?

P4: What was the role of the mentor in the relationship with the mentee in the opinion of the students?

P5: What is the relationship between the knowledge, skills and attitudes from particular developmental layers and the roles played by mentors in the opinion of students?

\section{2. Measures}

In order to answer the research questions, a questionnaire was constructed. Questions regarding the knowledge, skills and attitudes of mentors as well as noticed competency gaps were developed on the basis of Stefan Kunowski's theory of integral development. The questions are included in the table 1.

Table 1a. Skills, knowledge, attitudes of the mentor from particular developmental layers

\begin{tabular}{|l|l|}
\hline Layer & Skills, knowledge, attitudes of the mentor \\
\hline Biological & - Concern for the health, safety and physical fitness of the learner \\
& - Concern for one's own health, safety and physical fitness \\
& - Concern for the hygiene of the learner's mental work \\
& - Concern for own hygiene of mental work \\
\hline
\end{tabular}


Table 1b. Skills, knowledge, attitudes of the mentor from particular developmental layers

\begin{tabular}{|c|c|}
\hline Layer & Skills, knowledge, attitudes of the mentor \\
\hline Psychological & $\begin{array}{l}\text { - Providing reliable knowledge, } \\
\text { - Sharing one's own professional experience by making materials, scenarios and } \\
\text { teaching resources available to the mentee } \\
\text { - Undertaking one's own self-improvement as a result of contact with the intern } \\
\text { - Providing information on how to proceed in a given situation }\end{array}$ \\
\hline Social & $\begin{array}{l}\text { - Establishing relationships of support, help, care } \\
\text { - Help in coping with difficulties or negative feelings } \\
\text { - Help in preparing for classes in terms of organisation of classes and social space } \\
\text { - Building a community }\end{array}$ \\
\hline Culture-creating & $\begin{array}{l}\text { - Transferring knowledge about culture and its values to students and pupils } \\
\text { - Co-creation of culture: general culture, culture of the school, preschool, class, } \\
\text { preschool group, } \\
\text { - Implementing values: } \\
\text { a) ultimate values (God, faith), } \\
\text { b) moral values (e.g. truth, justice) } \\
\text { c) personal values of everyday life (e.g. family life, home, companionship) } \\
\text { d) social values (e.g. nation, homeland) } \\
\text { e) cognitive values (e.g. wisdom, knowledge) } \\
\text { f) vital values (e.g. health, life) } \\
\text { g) hedonistic values (e.g. fun, pleasure) } \\
\text { h) material values (e.g. money) }\end{array}$ \\
\hline Worldview & $\begin{array}{l}\text { - Noticing the purpose and meaning of one's actions - the mentor informed the } \\
\text { student about them } \\
\text { - Giving a testimony of faith } \\
\text { - Evangelising }\end{array}$ \\
\hline
\end{tabular}

The task of the respondents was to refer to the statement on a three-point ordinal scale. The described skill, knowledge or attitude could be present to a high or low degree, or not present at all (none). Additionally, respondents could mark the answer "No opinion"which was equated with a lack of knowledge on a given topic.

In terms of the role of the mentor in relation to the mentee, 5 roles were defined (observer, colleague, master, boss and know-it-all). Descriptions of particular roles were included in the question so that they could be clear to the respondent. The answers made up a nominal scale (table 2). 
Table 2. Description of the roles played by the mentor in relation to the teaching intern during the internship

\begin{tabular}{|l|l|}
\hline $\begin{array}{l}\text { Name of the } \\
\text { role }\end{array}$ & Description of the mentor's role \\
\hline Observer & Not taking the initiative with the intern's actions, just watching them \\
\hline Colleague & $\begin{array}{l}\text { Showing a lot of warmth and support to the intern, the experience of the mentor and } \\
\text { mentee was on a similar level }\end{array}$ \\
\hline Master & $\begin{array}{l}\text { With a wide range of experiences, often offering guidelines to the intern, warm and } \\
\text { supportive. Constantly developing himself/herself. }\end{array}$ \\
\hline Boss & Only assigned specific tasks to be performed. \\
\hline "Know-it-all" & $\begin{array}{l}\text { Looking with disregard and disapproval at the actions taken by the intern, pointing } \\
\text { out mistakes with satisfaction. }\end{array}$ \\
\hline
\end{tabular}

The task of the students was to determine which role was played by their mentor during the internship. Additionally, the students could choose the answer that the mentor did not fulfil any of the roles.

The last of the questions in the survey was an open-ended question about the ideal mentor. The respondents could express their opinion on this issue after completing the internship.

\subsection{Participants and procedure}

The John Paul II Catholic University of Lublin is a partner of the international PROMENTORS project, the aim of which is to develop an optimal mentoring model and to design courses for mentors taking care of young teachers in Israel ${ }^{2}$. The present article is the result of work in the above-mentioned project. 73 students of education and special education of the John Paul II Catholic University of Lublin participated in the study. The vast majority of the respondents were women (71 persons). Only students who had completed pedagogical internship preparing them for the profession of a pre-school and early-school education teacher, special education teacher and counsellor were asked to fill in the questionnaire. Due to limitations in the functioning of universities caused by the COVID epidemic, the questionnaire was placed on the Microsoft Teams platform intended for online classes and sent to interested students by e-mail.

The analysis of individual questions in the survey included a qualitative and quantitative analysis.

The qualitative analysis concerned the open-ended question related to the knowledge, skills and attitudes of an ideal mentor in the opinion of students and was

${ }^{2}$ https://www.erasmusplus.org.il/promentors 
developed around the most frequent topics and terms describing mentors; the most frequently repeated words in the mentor-mentee relationship were also analysed.

The quantitative analysis consisted of two stages. The first stage involved calculating the frequencies of individual answers to the questions concerning knowledge, skills and attitudes from particular developmental layers implemented by mentors and the roles played by mentors during the internship. The second stage of the analysis was to rank individual responses. The answers "to a high degree" were given a score of 2, the answers "to a low degree" were assigned a score of 1 , and the answers "not at all" were assigned a score of 0 . The collected data were analysed using PS IMAGO PRO 5.1 (software package), which contains IBM SPSS Statistics 25 (Polish version). Descriptive statistics are presented using the median, skew, maximum and minimum score. The answer "No opinion" was qualified as missing data. Differences in the degree of implementation of values were calculated in the group of mentors that students referred to as masters and in the group where students chose other terms to describe the mentors. The nonparametric MannWhitney U test was used. The significance level was set a priori at $\mathrm{p} \leq 0.05$.

\subsection{Findings}

In order to answer the question what skills, knowledge and attitudes education students expect from their mentors during their internships, the respondents were asked what an ideal mentor should be like. Responses were grouped by area: knowledge, skills and attitudes. The table 3 shows the catalogue of student responses concerning each of the above areas. The data presented in the table 3 indicate that, in the students' opinion, there are certain attitudes that are the most desirable in the image of an ideal mentor. Among the general statements describing the whole person of the mentor, he or she was presented as a person who is one step further from the mentee, but close enough to keep up with them. This is comparable to General Eisenhower's approach to leadership, expressed in the words "don't push, pull!" This example was also used by one of the surveyed students. It is also worth emphasising that the students' statements indicated that the knowledge, skills, as well as attitudes of the ideal mentor should be focused on his or her relationship with the mentee.

Table 3. Catalogue of the characteristics of an ideal mentor in the opinion of students

\begin{tabular}{|l|l|}
\hline Area & Features of an ideal mentor \\
\hline Knowledge & - intelligent, \\
& - with extensive knowledge and competencies, \\
& - formulates advice and guidelines related to work, \\
& - with extensive experience that they share, \\
& - gaining knowledge from the intern \\
\hline Skills & - provides help, \\
\hline
\end{tabular}




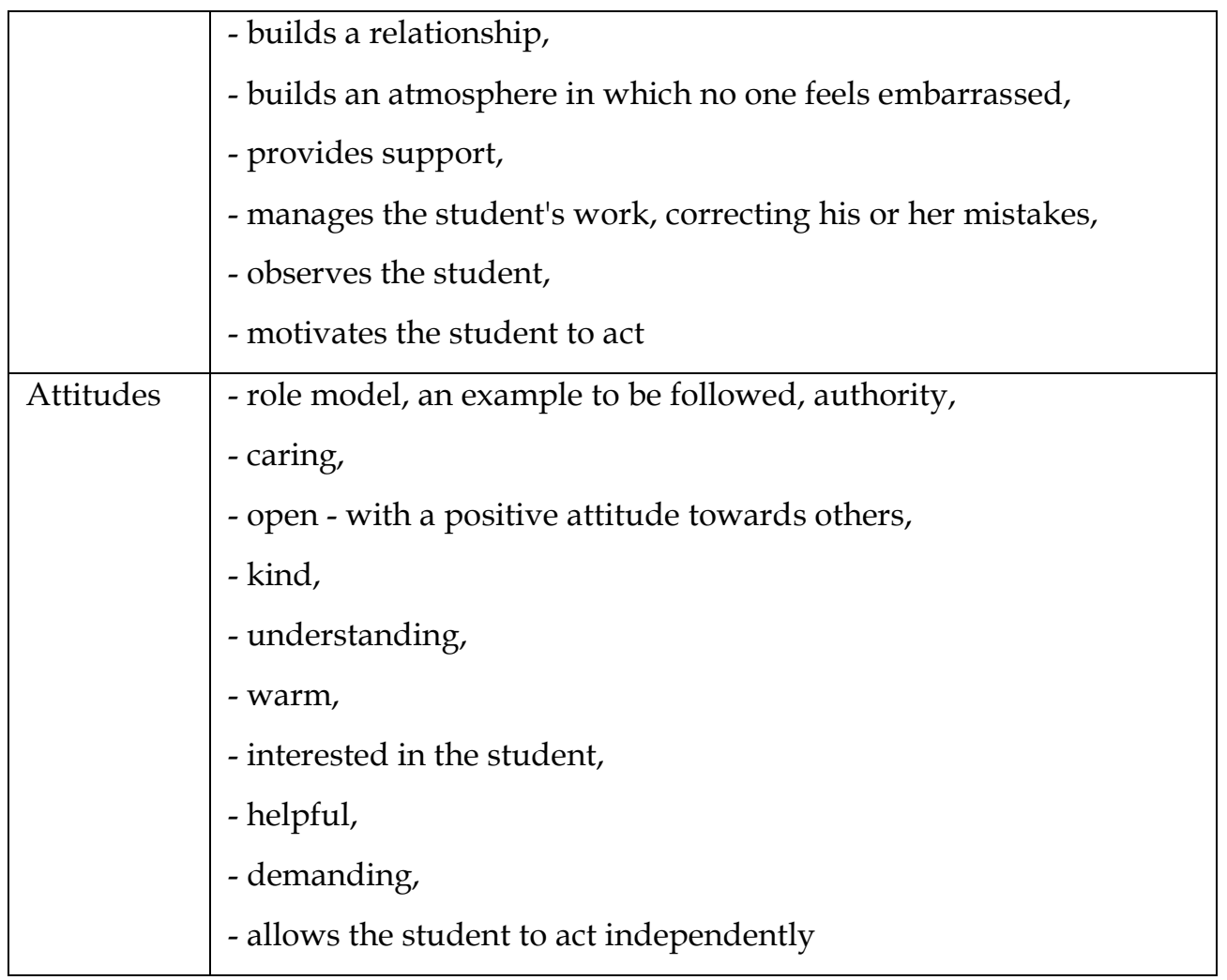

They constitute a certain resource open to the needs of the learner.

It is worth noting that several statements mentioned specific behaviours that should definitely not be presented by an ideal mentor. The respondents indicated imposing one's own ideas, judging, criticising, causing stress to the intern, interfering in every matter, and generally looking down on the intern.

In terms of the research question concerning knowledge, skills and attitudes from particular developmental layers implemented by mentors during internships, the results of students' assessment will be presented on the basis of their types. In terms of knowledge, skills and attitudes from the biological layer, the majority of education students declared that during their internships, the attitude of taking care of health, safety and fitness was present to a high degree among their mentors (in $69.9 \%$ cases), as well as the attitude of showing concern for the intern's health, safety and fitness (in 74\% cases). Similarly, in the case of mental hygiene, students' statements prove that their mentors took care of their own hygiene of mental work (77.5\%) and showed concern for the mental hygiene of the student $(83.6 \%)$. Three out of the four charts relating to individual questions in this layer show a very strong left-skewness, which additionally proves the accumulation of high scores for mentors. Statistics are presented in Table 4. 
Table 4. Descriptive statistics for questions concerning the assessment of knowledge, skills and attitudes of mentors in the biological layer

\begin{tabular}{|c|c|c|c|c|c|c|c|c|c|c|c|c|}
\hline \multirow{3}{*}{$\begin{array}{l}\text { Mentor's knowledge, skills and } \\
\text { attitudes relevant to the biological } \\
\text { layer }\end{array}$} & \multicolumn{8}{|c|}{$\begin{array}{l}\text { The degree of implementation of particular } \\
\text { competencies by mentors as assessed by students }\end{array}$} & \multirow[t]{3}{*}{$\mathrm{Me}$} & \multirow[t]{3}{*}{ Skewness } & \multirow[t]{3}{*}{ Min } & \multirow[t]{3}{*}{ Max } \\
\hline & \multicolumn{2}{|c|}{ High } & \multicolumn{2}{|c|}{ Low } & \multicolumn{2}{|c|}{ None } & \multicolumn{2}{|c|}{ No opinion } & & & & \\
\hline & $\mathrm{N}$ & $\%$ & $\mathrm{~N}$ & $\%$ & $\mathrm{~N}$ & $\%$ & $\mathrm{~N}$ & $\%$ & & & & \\
\hline $\begin{array}{l}\text { Concern for the health, safety and } \\
\text { physical fitness of the teaching } \\
\text { intern }\end{array}$ & 54 & 74 & 4 & 5.5 & 5 & 6.8 & 10 & 13.7 & 2 & -2.503 & 0 & 2 \\
\hline $\begin{array}{l}\text { Concern for their own health, } \\
\text { safety and physical fitness }\end{array}$ & 51 & 69.9 & 1 & 1.4 & 3 & 4.1 & 18 & 24.7 & 2 & -4.177 & 0 & 2 \\
\hline $\begin{array}{l}\text { Concern for the hygiene of the } \\
\text { mentee's mental work }\end{array}$ & 61 & 83.6 & 4 & 5.5 & 1 & 1.4 & 7 & 9.6 & 2 & -4.051 & 0 & 2 \\
\hline $\begin{array}{l}\text { Concern for their own hygiene of } \\
\text { mental work }\end{array}$ & 55 & 77.5 & 3 & 4.2 & 1 & 1.4 & 12 & 16.9 & 2 & -4.156 & 0 & 2 \\
\hline
\end{tabular}

In terms of psychological competencies (table 5), especially cognitive competencies, most of the mentors (89\%) provided students with reliable knowledge, shared their own professional experience by providing materials, scenarios, teaching resources (89\%), and transferred knowledge about how to proceed in a given situation $(79 \%)$. In addition, the students reported that in $61 \%$ of cases, the attitude of undertaking self-improvement as a result of contact with the intern was present in mentors to a high degree. In the discussed psychological layer, the competency with the highest scores was the transfer of reliable knowledge to the intern, as evidenced by the high index of left-skewness of the answers $(\mathrm{SKE}=-4.770)$.

Table 5. Descriptive statistics for questions regarding the assessment of knowledge, skills and attitudes of mentors in the psychological layer

\begin{tabular}{|c|c|c|c|c|c|c|c|c|c|c|c|c|}
\hline \multirow[t]{3}{*}{$\begin{array}{l}\text { Mentor's knowledge, skills and attitudes } \\
\text { relevant to the psychological layer }\end{array}$} & \multicolumn{8}{|c|}{$\begin{array}{l}\text { The degree of implementation of particular } \\
\text { competencies by mentors as assessed by students }\end{array}$} & \multirow[t]{3}{*}{$\mathrm{Me}$} & \multirow[t]{3}{*}{$\begin{array}{l}\text { Skewn } \\
\text { ess }\end{array}$} & \multirow[t]{3}{*}{ Min } & \multirow[t]{3}{*}{$\begin{array}{l}\mathrm{Ma} \\
\mathrm{x}\end{array}$} \\
\hline & \multicolumn{2}{|c|}{ High } & \multicolumn{2}{|c|}{ Low } & \multicolumn{2}{|c|}{ None } & \multicolumn{2}{|c|}{ No opinion } & & & & \\
\hline & $\mathrm{N}$ & $\%$ & $\mathrm{~N}$ & $\%$ & $\mathrm{~N}$ & $\%$ & $\mathrm{~N}$ & $\%$ & & & & \\
\hline $\begin{array}{l}\text { Transferring reliable knowledge to the } \\
\text { intern }\end{array}$ & 65 & 89 & 3 & 4.1 & 1 & 1.4 & 4 & 5.5 & 2 & -4.770 & 0 & 2 \\
\hline $\begin{array}{l}\text { Sharing professional experience with the } \\
\text { intern by making materials, scenarios and } \\
\text { teaching resources available to them }\end{array}$ & 65 & 89 & 4 & 5.5 & 3 & 4.1 & 1 & 1.4 & 2 & -3.370 & 0 & 2 \\
\hline $\begin{array}{l}\text { Undertaking self-improvement as a result } \\
\text { of contact with the intern }\end{array}$ & 45 & 62.5 & 6 & 8.3 & 2 & 2.8 & 19 & 26.4 & 2 & -2.629 & 0 & 2 \\
\hline $\begin{array}{l}\text { Providing information on how to proceed } \\
\text { in a given situation }\end{array}$ & 58 & 79.5 & 7 & 9.6 & 4 & 5.5 & 3 & 4.1 & 2 & -2.293 & 0 & 2 \\
\hline
\end{tabular}


As far as the social layer is concerned, in the students' opinion, the following attitudes were present in mentors to a high degree: building a community ( $74 \%$ of responses), helping interns to cope with difficulties and negative feelings (61.1\% of responses), establishing a relationship of support, care and concern (84.9\% of responses), and also helping students in organising classes and social space (65.3\%). None of the students assigned the rating of 0 to the question concerning establishing relationships (Min = 1), which means that mentors always established a relationship of support, help and care with their interns according to the opinion of the latter (table 6).

Table 6. Descriptive statistics for questions concerning the assessment of knowledge, skills and attitudes of mentors in the social layer

\begin{tabular}{|c|c|c|c|c|c|c|c|c|c|c|c|c|}
\hline \multirow{3}{*}{$\begin{array}{l}\text { Mentor's knowledge, skills and } \\
\text { attitudes relevant to the social } \\
\text { layer }\end{array}$} & \multicolumn{8}{|c|}{$\begin{array}{l}\text { The degree of implementation of particular } \\
\text { competencies by mentors as assessed by students }\end{array}$} & \multirow[t]{3}{*}{ Me } & \multirow[t]{3}{*}{ Skewness } & \multirow[t]{3}{*}{ Min } & \multirow[t]{3}{*}{ Max } \\
\hline & \multicolumn{2}{|c|}{ High } & \multicolumn{2}{|c|}{ Low } & \multicolumn{2}{|c|}{ None } & \multicolumn{2}{|c|}{ No opinion } & & & & \\
\hline & $\mathrm{N}$ & $\%$ & $\mathrm{~N}$ & $\%$ & $\mathrm{~N}$ & $\%$ & $\mathrm{~N}$ & $\%$ & & & & \\
\hline $\begin{array}{l}\text { Establishing relationships of } \\
\text { support, help, care }\end{array}$ & 62 & 84.9 & 6 & 8.2 & 0 & 0 & 4 & 5.5 & 2 & -2.696 & 1 & 2 \\
\hline 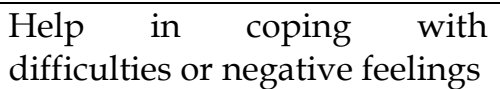 & 44 & 61.5 & 6 & 8.3 & 5 & 6.9 & 17 & 23.6 & 2 & -2.012 & 0 & 2 \\
\hline $\begin{array}{l}\text { Help in preparing for classes } \\
\text { in terms of organisation of } \\
\text { classes and social space }\end{array}$ & 47 & 65.3 & 11 & 15.3 & 5 & 6.9 & 9 & 12.5 & 2 & -1.706 & 0 & 2 \\
\hline Building a community & 54 & 74 & 8 & 11 & 1 & 1.4 & 10 & 13.7 & 2 & -2.611 & 0 & 2 \\
\hline
\end{tabular}

In terms of the culture-creating layer (table 7), mentors showed the attitude of creating the school's culture to a high degree (75\% of responses), as well as that of providing pupils and students with knowledge about culture and its values (64.4\%). The most frequently implemented values during the internships were personal values of everyday life (family life, home, companionship; $82.2 \%$ of the respondents chose the answer "to a high degree", SKE = -4.353), cognitive values $(84.9 \%$, SKE $=-4,086)$, moral values (e.g. truth and justice; 78\%), as well as vital values (health, life; $76.4 \%$ ). In the question about personal values, the minimum value was 1 , which means that, in the student's opinion, these values were always present in education during the internship. Next followed hedonistic values ( $58.9 \%$ of the respondents chose the answer "to a high degree"), social values, e.g. nation, homeland (58.9\%), ultimate values (God - 37\%) and material values (17\%). 
Table 7. Descriptive statistics for questions concerning the assessment of knowledge, skills and attitudes of mentors in the culture-creating layer

\begin{tabular}{|c|c|c|c|c|c|c|c|c|c|c|c|c|}
\hline \multirow{3}{*}{$\begin{array}{l}\text { Mentor's knowledge, skills and } \\
\text { attitudes relevant to the culture- } \\
\text { creating layer }\end{array}$} & \multicolumn{8}{|c|}{$\begin{array}{l}\text { The degree of implementation of particular } \\
\text { competencies by mentors as assessed by students }\end{array}$} & \multirow[t]{3}{*}{$\mathrm{Me}$} & \multirow[t]{3}{*}{$\begin{array}{l}\text { Skewnes } \\
\mathrm{s}\end{array}$} & \multirow[t]{3}{*}{$\begin{array}{l}\mathrm{Mi} \\
\mathrm{n}\end{array}$} & \multirow[t]{3}{*}{$\begin{array}{l}\text { Ma } \\
x\end{array}$} \\
\hline & \multicolumn{2}{|c|}{ High } & \multicolumn{2}{|c|}{ Low } & \multicolumn{2}{|c|}{ None } & \multicolumn{2}{|c|}{ No opinion } & & & & \\
\hline & $\mathrm{N}$ & $\%$ & $\mathrm{~N}$ & $\%$ & $\mathrm{~N}$ & $\%$ & $\mathrm{~N}$ & $\%$ & & & & \\
\hline $\begin{array}{l}\text { provided students and pupils with } \\
\text { knowledge about culture and its } \\
\text { values }\end{array}$ & 47 & 64.4 & 7 & 9.6 & 4 & 5.5 & 15 & 20.5 & 2 & -2.166 & 0 & 2 \\
\hline $\begin{array}{l}\text { co-created general culture, the } \\
\text { culture of the school, preschool, } \\
\text { class, preschool group }\end{array}$ & 54 & 75 & 4 & 5.6 & 5 & 6.9 & 9 & 12.5 & 2 & -2.503 & 0 & 2 \\
\hline $\begin{array}{l}\text { implemented ultimate values (God, } \\
\text { faith) }\end{array}$ & 27 & 37 & 10 & 13.7 & 7 & 9.6 & 28 & 38.4 & 2 & -0.919 & 0 & 2 \\
\hline $\begin{array}{llll}\text { implemented } & \text { moral } & \text { values } & \text { (e.g. } \\
\text { truth, justice) } & & & \end{array}$ & 57 & 78.1 & 3 & 4.1 & 3 & 4.1 & 10 & 13.7 & 2 & -3.353 & 0 & 2 \\
\hline $\begin{array}{l}\text { implemented personal values of } \\
\text { everyday life (e.g. family life, home, } \\
\text { companionship) }\end{array}$ & 60 & 82.2 & 3 & 4.1 & 0 & 0 & 10 & 13.7 & 2 & -4.353 & 1 & 2 \\
\hline $\begin{array}{l}\text { implemented social values (e.g. } \\
\text { nation, homeland) }\end{array}$ & 43 & 58.9 & 8 & 11 & 4 & 5.5 & 18 & 24.7 & 2 & -1.950 & 0 & 2 \\
\hline $\begin{array}{l}\text { implemented cognitive values (e.g. } \\
\text { wisdom, knowledge) }\end{array}$ & 62 & 84.9 & 4 & 5.5 & 1 & 1.4 & 6 & 8.2 & 2 & -4.086 & 0 & 2 \\
\hline 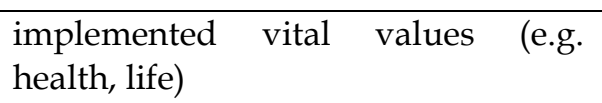 & 55 & 76.4 & 3 & 4.2 & 2 & 2.8 & 12 & 16.7 & 2 & -3.751 & 0 & 2 \\
\hline $\begin{array}{l}\text { implemented hedonistic values (e.g. } \\
\text { fun, pleasure) }\end{array}$ & 43 & 58.9 & 10 & 13.7 & 4 & 5.5 & 16 & 21.9 & 2 & -1.775 & 0 & 2 \\
\hline $\begin{array}{l}\text { implemented material values (e.g. } \\
\text { money) }\end{array}$ & 13 & 17.8 & 20 & 27.4 & 16 & 21.9 & 24 & 32.9 & 1 & -0.108 & 0 & 2 \\
\hline
\end{tabular}

In terms of the worldview layer, most of the mentors, in the opinion of students, noticed the meaning and purpose of their actions and informed the students about it $(74 \%$ of responses); however, it was not always a religious goal. Only $31.5 \%$ of the mentors gave a testimony of their faith and $23.3 \%$ were highly engaged in evangelisation. Some of the students did not have an opinion regarding the religious sphere in relation to the mentor of their internship (table 8). 
Table 8. Descriptive statistics for questions concerning the assessment of knowledge, skills and attitudes of mentors in the worldview layer

\begin{tabular}{|c|c|c|c|c|c|c|c|c|c|c|c|c|}
\hline \multirow{3}{*}{$\begin{array}{l}\text { Mentor's knowledge, skills and } \\
\text { attitudes relevant to the } \\
\text { worldview layer }\end{array}$} & \multicolumn{8}{|c|}{$\begin{array}{l}\text { The degree of implementation of particular } \\
\text { competencies by mentors as assessed by students }\end{array}$} & \multirow[t]{3}{*}{$\mathrm{Me}$} & \multirow[t]{3}{*}{$\begin{array}{l}\text { Skewnes } \\
\mathrm{s}\end{array}$} & \multirow[t]{3}{*}{ Min } & \multirow[t]{3}{*}{ Max } \\
\hline & \multicolumn{2}{|c|}{ High } & \multicolumn{2}{|c|}{ Low } & \multicolumn{2}{|c|}{ None } & \multicolumn{2}{|c|}{ No opinion } & & & & \\
\hline & $\mathrm{N}$ & $\%$ & $\mathrm{~N}$ & $\%$ & $\mathrm{~N}$ & $\%$ & $\mathrm{~N}$ & $\%$ & & & & \\
\hline $\begin{array}{l}\text { Saw the purpose and meaning } \\
\text { of his/her actions - informed } \\
\text { you about them }\end{array}$ & 54 & 74 & 6 & 8.2 & 4 & 5.5 & 9 & 12.3 & 2 & -2.476 & 0 & 2 \\
\hline $\begin{array}{l}\text { Gave a testimony of his/her } \\
\text { faith }\end{array}$ & 23 & 31.5 & 10 & 13.7 & 15 & 20.5 & 24 & 32.9 & 1 & -0.291 & 0 & 2 \\
\hline Was engaged in evangelisation & 17 & 23.3 & 7 & 9.6 & 21 & 28.9 & 28 & 38.4 & 1 & -0.182 & 0 & 2 \\
\hline
\end{tabular}

As it can be seen from the results presented above referring to tables $3-7$, the most frequent value for most of the questions is 2 , which means that individual competencies are present in the behaviour of mentors to a high degree. The exceptions are religious competencies, which are implemented to a low degree $(\mathrm{Me}=1)$, and material values $(\mathrm{Me}=$ 1). All the distributions turned out to be left-skewed to varying degrees, which means that the students attributed to their mentors behaviours that attested to the high competencies of the latter.

When it comes to the research question regarding the roles of mentors during internships, more than half of the students indicated that their mentor was a master for them $(52.1 \%)$; the role of the observer was chosen by $20 \%$ of students, of a colleague $-12.3 \%$, and the boss $-8.2 \%$ (table 9).

Table 9. Number $(\mathrm{N})$ and percentage of answers given to the question: What role did the mentor play during your internship?

\begin{tabular}{|l|c|c|l|c|c|}
\hline Answers & $\mathrm{N}$ & $\%$ & Boss & 6 & 8.2 \\
\hline Observer & 15 & 20.6 & “Know-it-all” & 0 & 0 \\
\hline Colleague & 9 & 12.3 & $\begin{array}{l}\text { Did not play any } \\
\text { of these roles }\end{array}$ & 3 & 4.1 \\
\hline Master & 38 & 52.1 & & \\
\hline
\end{tabular}


For statistical purposes, all observations were divided into two groups. The first group consisted of people who declared that their mentor played the role of a master (which was assumed to be an exemplary role for mentoring); the second group consisted of people who selected other roles. The authors decided to check what the differences were between mentors perceived as masters and mentors perceived differently in terms of their competencies and implemented values. The differences are shown in Table 10.

Table 10. Differences in competencies between mentors described as masters and other mentors

\begin{tabular}{|c|c|c|c|c|c|}
\hline \multicolumn{2}{|l|}{ Question } & $\begin{array}{l}\text { group of } \\
\text { mentors } \\
\text { perceived as } \\
\text { masters }\end{array}$ & $\begin{array}{lr}\text { group } & \text { of } \\
\text { mentors } & \text { not } \\
\text { perceived } & \text { as } \\
\text { masters } & \end{array}$ & Z & $\mathrm{p}$ \\
\hline \multirow{11}{*}{$\begin{array}{l}\text { Mark the extent to } \\
\text { which the mentor } \\
\text { of your internship }\end{array}$} & $\begin{array}{l}\text { showed concern for your health, } \\
\text { safety and physical fitness }\end{array}$ & 34.76 & 28.31 & $-\overline{2}-388$ & 0.17 \\
\hline & $\begin{array}{l}\text { cared for his or her own health, } \\
\text { safety and physical fitness }\end{array}$ & 28.35 & 27.43 & - & 0.568 \\
\hline & $\begin{array}{l}\text { showed concern for the hygiene of } \\
\text { your mental work }\end{array}$ & 36.00 & 30.31 & - & $0.009^{* *}$ \\
\hline & $\begin{array}{l}\text { cared for the hygiene of his or her } \\
\text { mental work }\end{array}$ & 31.00 & 27.22 & - & $0.030^{*}$ \\
\hline & $\begin{array}{l}\text { provided you with reliable } \\
\text { knowledge }\end{array}$ & 36.62 & 34.10 & $-\overline{1}-343$ & 0.179 \\
\hline & $\begin{array}{l}\text { shared his or her professional } \\
\text { experience }\end{array}$ & 39.12 & 33.41 & - & 0.20 \\
\hline & $\begin{array}{l}\text { undertook own self-improvement } \\
\text { as a result of contact with the } \\
\text { intern }\end{array}$ & 31.00 & 22.52 & - & $0.001^{* *}$ \\
\hline & $\begin{array}{l}\text { provided information on how to } \\
\text { proceed in a given situation }\end{array}$ & 38.69 & 31.48 & $-\bar{l}-362$ & $0.018^{*}$ \\
\hline & $\begin{array}{l}\text { established a relationship of } \\
\text { support, help, care }\end{array}$ & 37.50 & 30.92 & - & $0.004^{* *}$ \\
\hline & $\begin{array}{l}\text { helped you in coping with } \\
\text { difficulties or negative feelings }\end{array}$ & 32.55 & 21.67 & - & $0.000^{* * *}$ \\
\hline & $\begin{array}{l}\text { helped you in preparing classes by } \\
\text { making materials, scenarios and } \\
\text { teaching resources available to you }\end{array}$ & 37.21 & 25.90 & - & $0.001^{* * *}$ \\
\hline
\end{tabular}




\begin{tabular}{|c|c|c|c|c|}
\hline built a community & 33.99 & 29.17 & $-\overline{1}-806$ & 0.071 \\
\hline $\begin{array}{l}\text { provided students and pupils with } \\
\text { knowledge about culture and its } \\
\text { values }\end{array}$ & 34.13 & 24.19 & - & $0.001^{* * *}$ \\
\hline $\begin{array}{l}\text { co-created general culture, the } \\
\text { culture of the school, preschool, } \\
\text { class, preschool group }\end{array}$ & 35.67 & 27.41 & - & $0.002^{* *}$ \\
\hline $\begin{array}{l}\text { implemented ultimate values } \\
\text { (God, faith) }\end{array}$ & 26.00 & 19.86 & $-\overline{1.788}$ & 0.74 \\
\hline $\begin{array}{l}\text { implemented moral values (e.g. } \\
\text { truth, justice) }\end{array}$ & 35.00 & 28.00 & - & $0.002^{* *}$ \\
\hline $\begin{array}{l}\text { implemented personal values of } \\
\text { everyday life (e.g. family life, } \\
\text { home, companionship) }\end{array}$ & 33.50 & 29.87 & $-\overline{2.171}$ & $0.030^{*}$ \\
\hline $\begin{array}{l}\text { implemented social values (e.g. } \\
\text { nation, homeland) }\end{array}$ & 30.52 & 24.75 & $-\overline{1}-838$ & 0.066 \\
\hline $\begin{array}{l}\text { implemented cognitive values (e.g. } \\
\text { wisdom, knowledge) }\end{array}$ & 34.72 & 33.12 & $-\overline{0}-806$ & 0.420 \\
\hline $\begin{array}{l}\text { implemented vital values (e.g. } \\
\text { health, life) }\end{array}$ & 32.19 & 27.96 & - & $0.044^{*}$ \\
\hline $\begin{array}{l}\text { implemented hedonistic values } \\
\text { (e.g. fun, pleasure) }\end{array}$ & 31.26 & 25.41 & - & 0.085 \\
\hline $\begin{array}{l}\text { implemented material values (e.g. } \\
\text { money) }\end{array}$ & 26.03 & 32.50 & $\begin{array}{l}- \\
0.651\end{array}$ & 0.515 \\
\hline $\begin{array}{l}\text { saw the purpose and meaning in } \\
\text { his or her actions and informed } \\
\text { you about them }\end{array}$ & 37.50 & 26.48 & - & $0.000^{* * *}$ \\
\hline gave a testimony of his or her faith & 24.19 & 25.78 & $\begin{array}{l}- \\
0.422\end{array}$ & 0.673 \\
\hline was engaged in evangelisation & 24.67 & 21.10 & $-\overline{0}-992$ & 0.321 \\
\hline
\end{tabular}

The data presented in the table 10 show that according to students, mentors perceived by them as masters had more diverse skills, knowledge and attitudes than mentors performing other roles. The most significant differences were revealed in the 
questions concerning the social layer. In the opinion of students, mentors-masters more often established relationships of support, help and care $(Z=-2.866, p=0.004)$, helped students to cope with difficult situations $(Z=-3.561, p=0.000)$, or provided materials for classes $(Z=-$ $3.561, p=0.000)$; they also showed how to proceed in a given situation $(Z=-2.362, p=0.018)$. Differences were also revealed in the culture-creating layer. Mentors-masters much more often than others passed on knowledge about culture and its values to students $(Z=-2.362, p$ $=0.018)$, and also contributed to the culture of the school or of the preschool group $(Z=-$ $3.308, p=0.002)$. The values transmitted more often by the masters were, in the students' opinion, personal $(Z=-2.171, p=0.030)$, moral $(Z=-3.044, p=0.002)$ and vital values $(Z=-$ $2.015, \mathrm{p}=0.044)$. In terms of the spiritual layer, they saw the meaning and purpose in their actions much more often than mentors who were not perceived as masters, and passed this information on to students $(Z=-3.739, p=0.000)$. In the cognitive layer, there were no differences between the two groups of mentors. This means that the students, when assessing various groups of mentors, declared that the masters, observers, colleagues, as well as bosses displayed an attitude of sharing their knowledge and experience to a similar - i.e. high - degree. In terms of the transfer of cognitive values, there were also no differences between the identified groups of mentors. Furthermore, there were no differences in the transmission of religious values, giving a testimony of faith and evangelisation.

\section{Discussion}

The results described above require summarising and interpretation.

In terms of the first research question, which concerned the knowledge, skills and attitudes of mentors expected by students, it can be generally said that ideal mentors not only provide students with valuable knowledge and share experience, but also, and perhaps above all, are a source of emotional support. Similar data were obtained by R. Ballantyne, B. Hansford and J. Parker (1995). The analysis of the obtained statements shows that the mentor is a person who provides the mentee with a sense of security by taking care of them. Thanks to these endeavours, the students could focus more on developing their own competencies in the field of organising the educational and didactic process. Behaviour that should characterise an ideal mentor is observing the mentee, entrusting them with tasks, but also reacting to difficulties arising in the student's work and correcting their mistakes. In their statements, the students emphasised their openness to criticism from the mentor, which was an important tool in the process of improving their professional skills. At the same time, the mentor should have an attitude that allows students to work independently with children and youth. The qualitative analysis of students' statements showed that the ideal mentor leaves the space for students to undertake their own actions; he or she is not a "supervisor" or "controller", but rather a kind, more experienced companion in a given 
activity. Moreover, the mentor himself or herself is also open to the use of new solutions. It is worth referring here to the analyses of J. Walkington (2005), who emphasised that not every teacher feels capable of fulfilling the function of a mentor. In the above context, it can be concluded that a teacher-mentor should be ready and mature to undertake educational and didactic work in a relationship with an adult who is both a learner and a colleague in the profession.

Summing up the analyses regarding the second research question concerning the competencies of mentors from institutions where the students underwent internships, it can be said in general that the assessment of the competencies of the mentors of education students in Poland turned out to be very positive. Most of the internship mentors assigned to students in schools and preschools have, in the opinion of the students, a variety of competencies. They are people who not only provide students with reliable knowledge and share their experience, but also show concern for mental hygiene and proper working relationships. Moreover, they transmit different values to students and see the meaning of their actions. The obtained research results provide additional confirmation for the data acquired by B. Davis and K. Higdona (2008); D. Richter (2013); A. Roehrig, C. Bohn, J. Turner, M. Pressley (2008); J. Boreen (2009); R. Viney and J. McKimm (2010); L. OrlandBarak (2014). However, it should be emphasised that the conducted analyses showed that, in the opinion of Polish students, the mentoring they experienced does not affect only some aspects of their person (as in the case of the above-mentioned authors) - it is not fragmentary; on the contrary, it affects each of the layers of the person - it is comprehensive and multidimensional.

Such a positive assessment may result from several factors. The professional advancement of a teacher in Poland requires teachers to undertake certain tasks in order to fulfil the requirements for a given position. One of these tasks may be taking care of teaching interns. Therefore, mentors, despite not receiving remuneration for performing that function, will obtain benefits in the future for fulfilling this task. On the other hand, the role of a mentor is not obligatory for the teacher; it is one of given possibilities and ultimately it is the teacher who voluntarily declares his or her readiness to perform this function. It can therefore be assumed that the mentor himself or herself finds joy and satisfaction in fulfilling this role. Teaching interns conduct classes under the supervision and with the consent of the mentor teacher, thus partially relieving the teacher of didactic tasks; they also help with taking care of children, preparing materials for classes, and, moreover, they are a source of academic knowledge for practising teachers. The creative attitude of the mentor is also important, as he or she undertakes his or her own self-improvement and introduces the mentee to cooperation with other institutions (i.e. psychological and pedagogical counselling centres, training institutions, libraries, experience exchange seminars, etc.) which co-create to the mentoring process. 
In terms of competency gaps (third research question), only the inability to refer to the religious layer in questions about giving a testimony of faith and evangelisation were observed. This is probably due to the fact that some students did their internships in secular institutions, where the issues of faith were not raised by mentors. Perhaps extending the time of the mentee's cooperation with the mentor would be the basis for activities in this field.

The analysis of the question about the role played by the mentor during the internship allows us to state that mentors were most often seen as masters, that is, people who had a wide range of experiences, often provided guidelines, were kind and supportive, and were constantly developing. A mentor described in this way can be considered exemplary, and the mentor-master - an authority in the relationship with the student. Additionally, the research shows that the features and values that distinguished the masters from other types of mentors were: establishing relationships of help and care, helping students in difficult situations, transferring personal, moral and vital values, as well as seeing the meaning and purpose of their own actions. It should be emphasised that the term "master" was used to describe a mentor several times in the conducted research. Both in the qualitative and quantitative part, the respondents described their mentors as masters in most cases. Moreover, they pointed out that their ideal mentor is a master and they had met a master during their internship. It is worth noting that significant differences in terms of the implemented skills, knowledge and attitudes, in relation to the role played by the mentor, were shown for the higher developmental layers: the social, culture-forming and spiritual layer. In this context, it is reasonable to formulate the conclusion that it is the competencies from these layers that determine the high effectiveness of mentoring activities. The importance of interactions in the social and culture-forming layers was stressed by J. Geherke (1984); M. Carter and R. Francis (2001); S. Whitaker (2000). However, no analyses have been found regarding the spiritual layer of the person from the perspective of mentoring.

The presented research is largely descriptive and diagnostic and is an attempt to apply the assumptions of S. Kunowski's comprehensive layer theory to mentoring, and therefore require further, in-depth analyses. The undertaken research issue will be continued and extended to include new scopes, so as to formulate the most precise pedagogical guidelines for mentoring in the teaching profession.

\section{Bibliography}

Achinstein, B, Fogo, B. (2015). Mentoring novices' teaching of historical reasoning:

Opportunities for pedagogical content knowledge development through mentorfacilitated practice, Teaching and Teacher Education, 45, 45-58, https:// doi.org/10.1016/j.tate.2014.09.002. 
Baran, M. (2017). 'The Importance of Mentoring in Employee Work Engagement - Based on Research of Company Employees in Poland', International Journal of Contemporary Management, 16(2), 33-56, https:/ / doi.org/10.4467/24498939IJCM.17.009.7522.

Boreen, J., Johnson, M.K., Niday, D., Potts, J. (2009). Mentoring Beginning Teachers: Guiding, Reflecting, Coaching, Portland, ME: Stenhouse Publishers.

Bressman, S., Winter S.J., Efron, E.S. (2019). Next generation mentoring: Supporting teachers beyond induction, Teaching and Teacher Education Volume 73, July 2018, 162-170. https:// doi.org/10.1016/j.tate.2018.04.003.

Browne, J. (2021), 'Excuse the cat...' Reflections on online mentoring during the COVID-19 pandemic. Med Educ, 55, 673-675, https://doi.org/10.1111/medu.14445.

Carter, M., \& Francis, R. (2001). Mentoring and Beginning Teachers' Workplace Learning. Asia-Pacific Journal of Teacher Education, 29(3), 249-262.

Chałas K. (2020). Inteligencja moralna jako czynnik warunkujący integralny rozwój młodego człowieka, (w): T. Przesławski (red.), Księga jubileuszowa z okazji 80-lecia urodzin dr hab. Krystyny Ostrowskiej, Warszawa: Wyd. Instytutu Sprawiedliwości.

Chałas, K. (2016). Introcepcja wartości, (w:) K. Chałas, A. Maj (red.), Encyklopedia Aksjologii Pedagogicznej, 460, Radom: Wyd. Polwen.

Davis, B., \& Higdon, K. (2008). The Effects of Mentoring/Induction Support on Beginning Teachers' Practices in Early Elementary Classrooms (K-3), Journal of Research in Childhood Education, 22(3), 261-274, https:/ / doi.org/10.1080/02568540809594626.

Domagała- Zyśk E. (2018). Integral Development of Students with Special Educational Needs in Inclusive Education from a Personalistic Perspective, Paedagogia Christiana, 2(42), 181-193, http://dx.doi.org/10.12775/PCh.2018.023.

Dorner, H., Kárpáti, A. (2010).Mentoring for Innovation: Key Factors Affecting Participant Satisfaction in the Process of Collaborative Knowledge Construction in Teacher Training, Journal of asynchronous learning networks JALN, 14 (4), 63.

Frankl, V.E. (1966). Logotherapy and Existential Analysis-A Review, American Journal of Psychotherapy, 20(2), 252-260.

Frankl, V.E. (1966). Self-Transcendence as a Human Phenomenon, Journal of Humanistic Psychology, 6(2), 97-106.

Fresko, B., \& Wertheim, C. (2006). Learning by mentoring: prospective teachers as mentors to children at-risk, Mentoring $\mathcal{E}$ Tutoring: Partnership in Learning, 14(2), 149-161, https:// doi.org/10.1080/13611260500493519.

Geeraerts, K., Tynjälä, P., Heikkinen H.L.T., Gijbels, D., Markkanen, I., Pennanen, M. (2014). Peer-group mentoring as a tool for teacher development, European Journal of Teacher Education 38(3), 1-20, https:// doi.org/10.1080/02619768.2014.983068.

Herrmann, U. (2015). Wilhelm Flitner zum 125. Geburtstag: Pädagoge - Goetheforscher Kulturphilosoph, (in:) R. Nicolaysen, Wilhelm Flitner (1889 - 1990) - ein Klassiker der 
Erziehungswissenschaft? Zur 125. Wiederkehr seines Geburtstags, 43-76, Hamburg: Hamburg University Press, https:/ / www.erasmusplus.org.il/ promentors.

Jauslin, S., Hernández, J., \& Schulte, V. (2021). Reverse Mentoring: Den Wissenstransfer zwischen Generationen gestalten, Schäffer-Poeschel Verlag für Wirtschaft Steuern Recht $\mathrm{GmbH}$.

Kluz, M. (2018). Sens ludzkiego życia i zdrowia - w duchu chrześcijańskiego personalizmu

Sens życia i zdrowia, Tarnowskie Studia Teologiczne, 37, 1-2, 281-297, http://dx.doi.org/10.15633/tst.3263.

Kowalski, K. (2019). Mentoring. The Journal of Continuing Education in Nursing, 50(12), 540541, http://dx.doi.org/10.3928/00220124-20191115-04.

Kunowski, S. (2004). Podstawy wspótczesnej pedagogiki, Wydawnictwo Salezjańskie. Warszawa. Kunowski, S. (2007). Podstawy wspótczesnej pedagogiki ([Wyd. 2].). Wydawnictwo Salezjańskie.

Martin, S.B. Michaud, M.E. Logerstedt, Ch.D. (2019). Faculty and Graduate Peer Mentors Online Experiences in Teaching and Mentoring, The Journal of General Education, 67(3-4), 251-268, https://doi.org/10.5325/jgeneeduc.67.3-4.0251.

Orland-Barak, L. (2014). Mediation in mentoring: A synthesis of studies in Teaching and Teacher Education, Teaching and Teacher Education, 44, 180-188. https:// doi.org/10.1016/j.tate.2014.07.011.

Pennanen, M., Heikkinen, H. L. T., \& Tynjälä, P. (2020). Virtues of Mentors and Mentees in the Finnish Model of Teachers' Peer-group Mentoring. Scandinavian Journal of Educational Research, 64 (3), 355 - 371, https:// doi.org/10.1080/00313831.2018.1554601.

Rhodes, J. E. (2020). Older and wiser : new ideas for youth mentoring in the 21st century . Harvard University Press. https://doi.org/10.4159/9780674250123.

Richter, D., Kunter, M., Lüdtke, O., Klusmann, U., Anders, Y., \& Baumert, J. (2013). How different mentoring approaches affect beginning teachers' development in the first years of practice, Teaching and Teacher Education, 36, 166-177, https:// doi.org/10.1016/j.tate.2013.07.012.

Roberts, A. (2000). Mentoring revisited: A phenomenological reading of the literature, Mentoring and Tutoring, 8(2), 145-170, https:/ / doi.org/10.1080/713685524.

Roehrig, A.D., Bohn, C.M., Turner, J.E., \& Pressley, M. (2008). Mentoring beginning primary teachers for exemplary teaching practices, Teaching and Teacher Education, 24(3), 684702, https:// doi.org/10.1016/j.tate.2007.02.008.

Rozporządzenie Ministra Nauki i Szkolnictwa Wyższego z dnia 25 lipca 2019 r. w sprawie standardu kształcenia przygotowującego do wykonywania zawodu nauczyciela [http://isap.sejm.gov.pl/isap.nsf/DocDetails.xsp?id=WDU20190001450]. 
Rynio, A. (2016). The integral education of a person as an opportunity to develop and retain human identity in "liquid modernity". In World Youth Days : a testimony to the hope of young people.

Thompson, C. (2019). The Magic of Mentoring: Developing Others and Yourself. Routledge, Taylor \& Francis Group, https:// doi.org/10.4324/9781315143477.

Viney, R., \& McKimm, J. (2010). Mentoring, British Journal of Hospital Medicine, 71(2), 106-109, https://doi.org/10.12968/hmed.2010.71.2.46491.

Wagner, I.,Wiśniewska-Śliwińska H. (2019). Postawy nauczycieli na podstawie badań, Pedagogika, Studia I Rozprawy, 2019, t. XXVIII, 83-96, http://dx.doi.org/10.16926/p.2019.28.07.

Walkington, J. (2005). Mentoring Preservice Teachers in the Preschool Setting: Perceptions of the role, Australasian Journal of Early Childhood, 30(1), 28-35, https:// doi.org/10.1177/183693910503000106.

Whitaker, S.D. (2000). Mentoring Beginning Special Education Teachers and the Relationship to Attrition, Exceptional Children, 66(4), 546-566, https:// doi.org/10.1177/001440290006600407. 